Open Access

\title{
Does ritual exist? Defining and classifying ritual based on belief theory
}

Qing Lan

Correspondence: adbag@sina.com School of Administration, Kunming University, Kunming, China

\begin{abstract}
With both the terms "rite of passage" and "ritual" facing difficulties as analytic concepts, we have no way to differentiate between common behavior, rite of passage, and ritual in a strict sense until today. Through careful reading, we find that van Gennep's original expressions of nearly all the basic features of the rite of passage are vague. The only thing we can ensure is that ritual object will change through the rite of passage. Gluckman tried to explain the rite of passage with social relations, but his effort failed because common behavior also changes social relations. By examining three cases - an airplane journey, llongot headhunting, and Yiche ancestor worship - we find that formalization, standardization, or routinization is not the essential element of ritual. The core of the problem is what people want to change through ritual. Applying belief theory as a way forward, we use the change of relations between two categories of mental existence but social relations for the definition of ritual. We then equate rite of passage with ritual and restrict ritual to religious behavior. Furthermore, according to the kinds of mental existence that we want to change in ritual, we classify two kinds of ritual.
\end{abstract}

Keywords: rite of passage, ritual, religion, belief anthropology, mental existence

Traveling away from home but not for the purpose of subsistence is a kind of human behavior that has been widespread in all societies since ancient times. However, it was not until the late twentieth century that tourism changed from a luxury of wealthy people to a general necessity of life. At the same time, tourism promoted the development of related industries around the world. Determining the coordinates of tourism in cultural anthropology and establishing an analytic framework of tourism are frequently the focus of research for tourism anthropologists.

Graburn and Nash, two important researchers in the anthropology of tourism, have debated these basic questions. Graburn $(1977,1983)$ suggests that tourism is a "modern ritual" in contemporary society. When people are away from home they are outside of their daily lives and in the travel life, which differs from routine work and life. When the travel ends people return to their previous daily life but with the experience of travel. Using Turner's classic analysis of pilgrimage, Graburn carries out the same structured treatment for tourism. Corresponding to Turner's ritual theory of structure-antistructure-structure, Graburn divides the life of the tourist into three stages: secular work-divine travel-secular work. Not long after Graburn presented his view of tourism as a rite of passage, Nash came up with the idea that the purpose of travel, the attitude toward travel, and the traveler's behavior vary from person to

(c) The Author(s). 2018 Open Access This article is distributed under the terms of the Creative Commons Attribution 4.0 International License (http://creativecommons.org/licenses/by/4.0/), which permits unrestricted use, distribution, and reproduction in any medium, provided you give appropriate credit to the original author(s) and the source, provide a link to the Creative Commons license, and indicate if changes were made. 
person, and not all kinds of travel are similar to pilgrimage. Graburn's points of view can thus be "a profitable way to analyze some tourism, but ... we should be wary about being trapped into any one conceptual scheme, particularly one that may be beginning to acquire a quality of truth in the minds of its proponents " (Nash 1984).

The question of what kind of behavior is a rite of passage seems more likely to occur among undergraduates than academics. The fact that two scholars immersed in anthropology for many years have debated this "superficial" issue is very interesting. The matter reminds us that as one of the basic concepts in the research of ritual, the rite of passage does not have a clear definition. We must therefore return to the topic of rites of passage to observe and study its meaning.

\section{The Meaning and Difficulty of the Rite of Passage}

In 1909 a French academic book titled Les Rites de Passage was published. The author, van Gennep, contributed an analytical framework for the ritual called the "rite of passage." Van Gennep lived at the beginning period of anthropology-sociology, and was dedicated to finding the general structure of ritual. The discussion of rites of passage began with the difference and separation between the profane and the sacred, which was the generally recognized proposition at that time. Van Gennep found that individuals must go through an intermediate stage in which they cross between the profane and the sacred. In general, when a member of a society changes, such as through birth, adulthood, marriage, or death, people usually need to hold a ritual for them to mark the changes or transitions of an individual. Van Gennep called these rituals rites of passage, all of which were to "accompany a passage from one situation to another or from one cosmic or social world to another." Furthermore, van Gennep subdivided these rituals into rites of separation, transition rites, and rites of incorporation (van Gennep 1960, 10-11). The book provides many examples. They are used not only to support the theory, but also to establish how to use this abstract theory regarding empirical cases. "Our interest lies not in the particular rites but in their essential significance and their relative positions within ceremonial wholes, that is, their order. ... The underlying arrangement is always the same. Beneath a multiplicity of forms, either consciously expressed or merely implied, a typical pattern always recurs: the pattern of the rites of passage(original italics)" (van Gennep 1960, 191).

Intentionally or unintentionally, the rite of passage refers to the basic structure of the ritual. It is a pity that this advanced study did not attract scholars' attention until the publication of the English translation in 1960, which triggered the rebirth of the topic of "rites of passage" academia. Meanwhile, some difficulties in the concept of "rites of passage" also rose to the surface.

According to Young's research, van Gennep's discussion of transition begins with the sacred-profane dichotomy. It is regrettable that Malinowski questioned the universality of this classification in 1913 (Young, 2004). It is rarely used today in anthropological research. If the sacred-profane dichotomy is not true, then we can naturally ask: what kind of individual attributes have changed before and after rites of passage? What is the meaning of transition?

Two years after the English translation of Les Rites de Passage appeared, a book edited by Gluckman was published. In this anthology Gluckman, Forts, Forde, and Turner, four leading anthropologists of the British school at that time, each wrote a paper on 
rites of passage. The title Essays on the Ritual of Social Relations expresses the consensus of the four authors. Following the research path of Durkheim and Radcliffe-Brown, Gluckman et al. placed investigating the change of social relations at the core position of studies of rites of passage, unequivocally maintaining the sociological explanation of ritual. In recognition of van Gennep's extraordinary insight, the anthology also emphasized the limitations of van Gennep's era. Van Gennep's statement “Acts of a special kind, derived from a particular feeling and a particular frame of mind" $(1960,1)$ is identified as a psychological explanation for rituals, which at this point was criticized and rejected.

Gluckman's article appeared as the first of the four papers, with the eye-catching French title "Les Rites de Passage" - the title of van Gennep's book. This seems to suggest the article's guiding position in the anthology, as well as the aim to challenge van Gennep. In the beginning of the essay Gluckman state that he would "set out his [van Gennep's] main theory, which was about the sequence of rites used to alter people's social relations. ... I argue that because he lacked an adequate theory about the nature of society he was unable to develop implications which he himself sensed in his major, very important, discovery" (Gluckman, 1962, 1). Forts echoes Gluckman in his thesis: after rites of incorporation, the individual incorporates "into a new structure of social structure, or conjuncture of the social relations." The reason why people hold a ritual is probably that the ritual changes the individual's status, role, or position (Fortes 1962, 55-57). In all four papers the sacred-profane dichotomy is not the core of the "rite of passage," but the transition of social relations is-individual social relations change before and after the ritual.

Victor Turner, the most important developer of van Gennep's transition model and also Gluckman's student, continues to investigate the change in social relations as a vital approach in the analysis of ritual. Turner inherited the three-stage analytical framework from van Gennep, which was further abstracted into structure-antistructure-structure processes. In Turner's view, before the separation phase begins social members are connected by a web of fixed social relationships. The daily norms of behavior control the behavior of people, and the social structure is in a stable state. The separation phase separates the ritual object from the previous society and takes him into the marginal phase. At marginal phase the ritual object is freed from the structure of society. His social position is unclear, and he can do something in violation of the daily standard, and the stable social structure is destroyed. Turner views this phase as antistructure, before it can be seen as structure. Finally, in the incorporation phase the ritual objects return to society. They establish new social relations with other members of society, daily norms are reaffirmed, and the society returns to a stable state. Turner argues that the marginal phase is the most important of the three stages, and is usually the longest part in the rite of passage because society needs to take advantage of this phase to break the original state of society and rebuild a new social relationship and structure. This is a dynamic process. Signs and symbols representing different social relations emerge unceasingly, showing their own strengths and becoming the arena of social relations with the final winner bringing people back to a new static structure (Turner 1969). Turner notes that the seemingly disruptive edge of society is ultimately a tool for society to strengthen its solidarity. For people who participate in transitional rituals such as pilgrimage, social differences between 
individuals and ranks will disappear in the edge phase and full equality between individuals will form a strong sense of mutual acceptance, creating a community without differences. The community will continue to exist after the stage of incorporation and social solidarity will be greatly strengthened (Turner 1969). We can see that after Turner's extension the rite of passage has the function of strengthening social cohesion, which is consistent with the main point of religion in Durkheim's Les formes élémentaires de la vie religieuse (Durkheim 1912). Ironically, though van Gennep was regarded as Durkheim's rival and pushed aside in his lifetime, through the efforts of Gluckman et al. his points have been integrated into the structure-functionalism (Turner 1974).

In the social relations approach, we also want to know if there is a one-to-one correspondence. Can we say that every ritual that changes people's social relations is a rite of passage? Conversely, are the rituals that do not change social relations not rites of passage? This also departs from the confusion in Les rites de passage. Van Gennep simply describes the rite of passage but does not define its boundaries. More problematically, van Gennep's text adds confusion to the following questions: is a rite of passage a kind of ritual, or a process model of ritual, or-to use a modern term-a ritual structure? In the beginning discussion of Les rites de passage, the rite of passage is not included in the sixteen categories (van Gennep 1960). After that it is then regarded as a ritual process many times, especially in the parts quoted earlier and in the book's conclusion. The rite of passage is thus meant to be a ritual structure. Also in the opening and conclusion, van Gennep presents an almost-contradictory judgment, "I do not maintain that all rites of birth, initiation, etc., are rites of passage only" (van Gennep 1960, 192-93, the same meaning also on p. 11). In some ethnic groups that see childbirth as a normal behavior, "the pattern will be transposed to the rites of childhood, or it may be included in the rites of betrothal and marriage"(van Gennep 1960, 193). Such a statement cannot be made without doubt. If the rite of passage is a ritual structure, how can it be discussed as a childhood, engagement, or wedding rite? It is clear that van Gennep was talking about a mixture of ritual structure and ritual purposes, and the "process pattern" in his text is not just a kind of abstract structure. We should forgive van Gennep since at the beginning of anthropology this type of defect was almost unavoidable. However, the question remains: what is the relationship between ritual, rite of passage, and social relations?

Gluckman (1962) distinguishes four kinds of ritual-magic action, religious action, substantive or constitutive ritual, and factitive ritual-clearly point out that rite of passage is a typical constitutive ritual. It is a pity that the standard of division is not the change in social relations because we cannot judge the precise positions of the rite of passage and the social relation. Turner conducts a deep study of rituals that have the structure of rites of passage, and is unable to answer the question. Should we use ideas like those of Leach, and see ritual as a communication level that all behaviors have (Leach 1954)? This actually removes the boundary between behavior, ritual, and rite of passage. It is followed by the proposition "in all human societies, the great majority of ceremonial occasions are 'rites of transition"' (Leach 1976, 35). Why most rather than all of them? What is the remaining part of the ritual? ${ }^{1}$ Leach does not provide an answer.

Van Gennep was also perplexed by the question of generation, "Neither their [rites'] close relationship nor its cause has been perceived, and the reason for resemblances 
among them has not been understood. And, above all, no one has shown why such rites $^{2}$ are performed in a specific order" (van Gennep 1960, vii). Whether van Gennep's original analysis or a more-elaborate frame after Turner's development, these all analyze the anatomy of ritual and cannot answer the generating question or why the same type of rite of passage shows huge differences between ethnic groups. The analysis of the rite of passage in different ethnic groups reminds us of another fact: although the process structure of different ethnic groups is the same, the specific behaviors are very different. After van Gennep the ethnography continues to enrich this ritual diversity-one side of human cultural diversity.

In the case of initiation, a Nuer boy in East Africa has to cut six long marks on his forehead with a sharp knife (Evans-Pritchard 1940). In Yunnan, China, a New Year ritual for children over the age of thirteen is to change their clothes; the boy wears trousers and the girl wears a skirt (Cai 2000,). In my field survey parents would build a "little house" for their children to live near the main house - the sign of the child becoming an adult. There is no specific age requirement for children to sleep apart from their parents. Each family determines the time according to their own economic and construction conditions, but usually when the child is between the ages of eight and thirteen years. Girls in Yiche begin to wear the hairstyle and the hat of a young girl. In addition, there is no observed initiation in Yiche. In today's Han village traditional initiation is almost dead.

Differences in initiation in ethnic groups is a common topic in anthropology. The few examples cited above emphasize that although initiation is usually regarded as a typical example of rite of passage, its complexity, duration, and even whether it exists or not show differences according to ethnic group. There is a spectrum of initiation ranging from none to complex. The cause of the spectrum is complex and opaque (Winzeler 2012). This means that we do not know what initiation is. Why do some people need a physical change to mark adulthood such as circumcision, which will bring children great physical pain especially in societies in which anesthesia technology has not been developed, while other people do not even need to change the type of clothes? Ritual changes in different times. People will create rituals, but also eliminate rituals. What triggers these changes? Van Gennep tried to classify rites and repeatedly stressed that initiation should not be considered as only a rite of passage. Can rite of passage be treated as a ritual type? If so, what other types of rituals are there? Or can we only use rite of passage as an analytical tool? Is there another ritual process pattern? Finally, as van Gennep knows, the identifiable degree of the three stages of the rite of passage differs in various ethnic groups regarding the same kind of ritual, or different rituals in one ethnic group (van Gennep 1960). What is the cause of these differences?

Gluckman's essay “Les rites de passage” puts forward two propositions with the aid of Durkheim's theory of social division of labor, trying to answer why tribal society, involving change in social status and general social relations, has a far higher degree of ritualization than modern society.

(a) the greater the secular differentiation of role, the less the ritual; and the greater the secular differentiation, the less mystical is the ceremonial of etiquette;

(b) the greater the multiplicity of undifferentiated and overlapping roles, the more the ritual to separate them. (Gluckman 1962, 34) 
The two propositions echo that time of one-line evolutionary theory and Weber's rationalization theory. Gluckman hopes to answer the generating question through the degree of differentiation in social roles. According to this hypothesis, it is easy to arrange the Nuer, $\mathrm{Na}$, Yiche, and Han into a sequence of degree of social differentiation degree from low to high. This order also represents their degree of social development and rationalization. Unfortunately the degree of social role differentiation is not accurate enough to make an evaluation of the whole society. Even if we can say the Nuer is in a lower degree of social differentiation, it is hard to prove that $\mathrm{Na}$, Yiche, and Han villagers have obvious differences in degree. When we focus on a particular ethnic group such as the Yiche, it is easy to find their social life filled with ritual activities. The Yiche not only have a large number of religious ritual experts, but ordinary people also bear the task of some certain rituals such as sacrificial rituals within the family house. So can we include the Yiche in a highly ritualized society? Why is it difficult to observe the existence of adult rituals in a society with highly complex funeral rituals? Why is there such a large gap between the same society's treatment of different roles? From Gluckman's proposition we can easily deduce that with modernization and rationalization processes the society will abandon rituals, but this claim has already been falsified. Religion and ritual have not been ended due to the secular (Stark and Bainbridge 1985). To this day it is highly ritualized that English people still talk about the weather (Fox 2004). Gluckman's theory inherits the genetic defect of functionalism theory: it cannot provide an effective explanation for the diversity and ritual changes in various ethnic groups. Noting the limitation of functionalism, Turner returns to the psychological way that Gluckman criticized, risking excessive interpretation and extensive use of psychoanalysis, and finally made a hodgepodge of functionalism, psychology, and structuralism (Turner 1967).

\section{Social Relations and Belief}

We have analyzed many difficulties in the concept of rite of passage. Gluckman believed that the change in social relations brought by ritual is the core of the rite of passage, but he did not realize that these changes originate in the identity change of members of society, which is clearly pointed out by van Gennep. Below I continue to explore the causes of identity change by using belief theory.

When people hold a ritual they always have an aim, some existence that is targeted at the ritual. We call the ultimate target existence the ritual object for convenience. Before and after the rite of passage the social identity of the ritual object changes, which is the most general purpose of the rite of passage. The social relationship between the self and others is determined by the social identity of the self and the other. Once the social identity changes, the social relationships of the self and other members of the community naturally shift. Further, social identity is a kind of social classification of individuals. The category of ritual objects can be changed by rites of passage. Humans are social animals that have to rely on classification to understand the world. We try to put everything in the world into a certain category (Durkheim and Mauss 1969). The human classification system satisfies the formal logic in most cases, and the classification itself implies the jump and fracture when we engage in classification activities. The position of the classification of existence can give us a sense of security. An unclear classification position means social relations can be uncertain, and people's behavior can appear 
chaotic because of the lack of reliability. In many cases the existence that has not been clearly classified can be considered unclean and dangerous (Douglas 1966). Rituals help to restore purity. Rites of passage are rituals that change the classification of things (Bourdieu 1980).

Classification is a judging process. Once completed, people will give the existence a classification position in the form of propositions, such as "Standing in front of me were allies, not enemies," "This fungus is poisonous and can't be eaten; that one is nontoxic and can be eaten," "It [intelligent being] has to put objects into categories so that it may apply its hard-won knowledge about similar objects, encountered in the past, to the object at hand" (Pinker 1998, 12). In belief theory, the belief in the proposition (I use the concept of belief only in this sense) dominates people's activities (Cai 2008). Once we make a judgment, it guides our way.

Specific to the classification process, the way we treat an object depends on which category we believe it belongs to, not what it actually belongs to. When we believe the person before us is a child we communicate with him/her in that way regardless of his/ her real age. When we believe that the fungus we harvest is nontoxic, we eat it. When we reexamine the rites of passage, we find that what happens before and after the ritual is nothing but our belief. For the Nuer and Ndembu, before a boy's initiation people believed that the ritual object was a child, regardless of their biological age; after the rite people believed that they were an adult, regardless of their biological age. The rite of passage changes our belief about the ritual object and the way we judge the ritual object. The Samo in Burkina Faso, who have an asymmetrical bilateral kinship system, have a wide range of social consanguinity that is banned from marrying (Cai 2008). Some couples have unfortunately discovered that they are in this prohibition range after their marriage. A remedial ritual can be held to cut off the culturally sanguine relationship between couples and legalize their marriage (Héritier 1999). We see that before the ritual the Samo believe that the two people are socially consanguineous and their marriage will do harm to the society. Upon the completion of the ritual people no longer believe that the two people are connected by a culturally sanguine relationship and the marriage becomes harmless.

The rite of passage inevitably involves a change in people's belief regarding the ritual object. The society holds that this change of belief requires a ritual. On the other hand, they believe that the change of a certain property of existence does not require a ritual and no such ritual will be observed. The presence or absence of a rite of passage and its degree of complexity is decided by beliefs on whether it is necessary or possible to change it through a ritual, and the difficulty of the degree of the change. For example, current Han villagers believe that the transition from child to adult is a biological process and no ritual is required. If the society can't accept a sudden change from A to B there may be a ritual to complete this transition. If there is no such ritual, the transition will not occur. For example, in Han society there is no ritual to remove social consanguinity; the only solution for such a marriage is divorce.

I argue that the rite of passage is the activity that aims to change people's beliefs. So are the activities that aim to change people's beliefs rites of passage? If the answer is yes, we can draw an equal sign between the actions that are intended to change people's beliefs and the rite of passage; if no, we need to determine which of those actions aimed at changing people's beliefs do not belong to the rite of passage. 


\section{Action, Belief, and Ritual}

Beliefs are the causes of people's actions. Before we act we make a judgment on the possible effects of this action, and begin to act only when we believe that the action will reach a certain valuable aim. We must act because we believe in the judgment that we have already made, and believe that our actions can change the state of the object of the action. On the surface, there is another type of behavior that is intended to keep the object steady rather than change it, but careful analysis shows that maintaining the state depends on certain aspects of guarding the object against possible changes, such as antiaging activities to keep fit or pleasing ancestors to maintain the family's well-being. All actions are intended to make some kind of change. Specific to ritual, we believe that the classification of ritual objects before and after our actions will change. Even if the daily ritual of ancestor worship is based on the judgment of the ancestors' satisfaction, we believe that ancestor worship can change the state of our ancestors from possible dissatisfaction to satisfaction. If we believe that after an action no one and/or none of the states of things will change-our beliefs regarding the action object will not change-then why should we carry out this action? People take a particular action because they believe in the function of the action. When people do not think the action will play a proper role they have three options: abolishing the action, changing the action, or introducing new actions. It can be seen that action must be intended to change our belief regarding the object of our actions. Of course, on occasion the action object will change their own beliefs about themselves because of the actions.

The rite of passage belongs to ritual, and the ritual belongs to action. The proposition for general action is also true for ritual. Like rites of passage, rituals are meant to change beliefs. Is there a difference between the rite of passage and the ritual? Grimes aims to distinguish different types of changes. "Ritual practices such as daily meditation and weekly worship are responses to recurring needs. These rites move but do not transform. By contrast, when effective rites of passage are enacted, they carry us from here to there in such a way that we are unable to return to square one. To enact any kind of rite is to perform, but to enact a rite of passage is also to transform" (Grimes $2000,7)$ Grimes seems to be distinguishing between movement and transformation according to the change in social roles, but can we say that there is no difference in social role between a daily prayer and a person who rarely prays? A change that never comes back cannot be defined as a transformation-a marriage can end in divorce, and death can be followed by reincarnation.

We now see that the rite of passage is a ritual to change belief. Action and ritual must be carried out to enact change in beliefs, so the rite of passage, ritual, and action are equal. However, this conclusion seems absurd. In general, we use ritual to "refer to any fixed or stereotyped practice, behavioral pattern, or embellishment that has no evident instrumental purpose beyond communication or symbolization" (Winzeler 2012). Let us look at two famous anthropological definitions of ritual. Ritual "denotes any activity with a high degree of formality and a nonutilitarian purpose" (Buckser 1997, 410). Ritual is "prescribed formal behavior for occasions not given over to technical routine, having reference to beliefs in mystical beings and powers" (Turner 1967, 19). Both of these cannot be used as a definition of ritual; they note the surface phenomena that apply to certain rituals without pointing out the entity of ritual. To make matters worse, they also use wrong and misleading words. Is it a highly formalized activity that 
we go to work every day at the same time? "Nonutilitarian purpose" should be judged from the perspective of contemporary natural science, but can we say that there is no practical purpose for praying for rain? In the latter statement the terms "technical routine," "mystical," "prescribed," and "formal" are difficult to clarify.

Here are three examples. The first case is the ordinary flight process from not long ago. When we want to travel by air, we must first buy plane tickets at the booking point, by telephone, or on the Internet. After that, we have to arrive at the airport at least half an hour before departure in order to obtain boarding passes, check luggage, and board the plane through security. When the plane arrives at its destination we get off the plane and leave the airport with our luggage. Anyone who has experienced air travel is familiar with this, and no one would ever view it as a ritual. However, with a simple analysis, we find that this process is in line with a rite of passage. The process of buying our ticket is similar to getting engaged, it is a separation ritual, and we begin building a relationship with the airline. With the boarding pass we enter a liminal phase. At this point we have constructed a social relationship with the airline. If we are late for boarding the airport will use a radio reminder to urge us to hurry or the plane may be delayed. However, the airport will not remind the passenger with a ticket but no boarding pass. After boarding all passengers in the same cabin form an anonymous passenger community until the flight is over. After we leave the plane we regroup into the social fabric. This process is clearly a prescribed, highly formalized behavior with no use of technology application or even faith in mystical power. A card with some printed symbols creates the relationship between the airline and airport.

The second case focuses on the headhunters of the Ilongot in the Philippines. The male looters at the headhunting wait for the best time to hit their victim, cut off his head, catch it before it falls on the ground, and then run away quickly. Headhunting success is believed to make the "older men discard the weight of age and recover the energy of their youth, whereas youths advance from novice status and adorn themselves with red hornbill earrings. To wear such earrings, they say, is to gain the admiration of young women" (Rosaldo, 1980, 140). For boys without a successful headhunt this is unquestionably a rite of passage; but for someone who is already a veteran hunter it is more a matter of filling their constant need. Obviously, since no one is waiting for you to hunt his head, the headhunting process is highly technical and flexible. There are no formal regulations or formal behavior associated with it.

The third case is ancestor worship. In my survey each family of Yiche needed to enact ancestor worship activities at various festivals. In most families these ancestral activities are performed independently by the hostess. Yiche is patrilineal and patrilocal. Before a married woman becomes a hostess, she must be taught how to worship from her husband's mother, but not her own mother. Ancestor worship activities are highly formalized, and are closely related to the mystical spirits of ancestors. The manner of ancestor worship is inherited only along the patrilineal line; there is no common standard for the entire ethnic group. The same phenomenon has also been observed in other areas. In the same or similar ethnic groups, the same ritual with the same name has a different pattern of behavior (Rappaport, 1984, 118).

Through the analysis above, we see that some daily routines that are usually not considered rituals are in many ways consistent with the core characteristics of the ritual. The Ilongot's headhunting is more likely to be referred to as a ritual rather than an 
ordinary behavior, but it does have a few characteristics of ritual. Yiche ancestor worship is obviously a ritual, but there are differences between any two patrilineages and is thus more like a daily activity. Both theoretical analysis and case study have shown how difficult it is to draw a line between rite of passage, ritual, and everyday behavior.

\section{The Way Out}

In his 1961 paper Jack Goody (1961) attempted to define ritual by means of the relationship between means and end. In 1977, Goody (1977) proposed the radical view that, given the inability to separate rituals from common practice, the use of rituals should be abandoned as an analytical concept. In this paper Goody reaches his conclusion without careful analysis of van Gennep's work on rites of passage or Gluckman's writing on social relationships, nor does he discuss his own 1961 definition. This work elicited little academic reaction, and other researchers continued to use ritual as an analysis object. With slight revisions, Goody's 1961 paper was reprinted in a 2010 anthology titled Myth and Ritual and the Oral (Goody 2010). The 1977 paper does not appear in this book and is never mentioned. This seems to suggest that Goody may have given up the route he took in 1977, and returned to his 1961 definition. Goody argues that in ritual "the relationship between the means and the end is not "intrinsic," but supplies no answer to what is intrinsic.

Facing Goody's negative argument, many scholars have abandoned the attempt to precisely define ritual. In the 1990s Bell questioned treating ritual as an entity (1992). She later emphasizes that there are cultural differences on whether a set of behaviors belongs to ritual. Bell suggests using a behavior spectrum ranging from rite behavior to class (rituallike), replacing the definition of ritual (1997).

Many scholars have expressed supporting or similar views to Bell's approach. Humphrey and Laidlaw argue that ritualization was the real core of the theory of ritual (1994). After examining numerous definitions of ritual between 1909 and 1991, Platvoet (1995) concludes that ceremony has a broad range. Snoek (2006) gives a very broad definition of ritual from the perspective of behavior. In their recent book (2014) Stewart and Strathern agree with Bell completely.

According to epistemology, it is equivalent to enlarge the extension of concept and to cancel it. In physics the range from $\gamma$ ray to far infrared are electromagnetic waves, they satisfy the basic equations of electromagnetic waves, and they do not become independent analytical concepts. According to Bell, the range from ritual to daily behavior is a behavior, so we can say some everyday behavior is rituallike behavior. We can also say that some ritual is a kind of daily behavior; there is no difference to cancel ritual.

Belief theory can reveal more clearly and concisely the significant difficulties hidden behind the existing ritual concepts and move our analysis a step forward. When Leach asserts that most rituals are rites of passage he does not tell us the other types of rituals, but he must be aware that the rite of passage model can explain most ritual. If we combine ritual, rite of passage, and action, it is natural to say that all of these actions are rites of passage, and that they can be naturally analyzed in three steps. When we generalize the transition ritual pattern to the analysis of all behaviors, we announce the end of ritual analysis. Thus if we cannot find revolutionary explanations, rituals and rites of passage must be abandoned. 
We have already concluded that all actions, including rituals, are intended to change. If ritual exists, it is then natural to conclude that the changes being sought by the ritual are different from those of the nonritual. In other words, if we succeed in finding a certain type of purpose, ritual with and non-ritual without, we can continue to use ritual in analysis. If we fail, we must abandon the usage of ritual.

In traditional use, rituals are usually associated with the supernatural and mysterious. One of the reasons why previous efforts failed is that these words cannot be used as concepts. In addition, one cause of confusion is that we do not know exactly what kind of entities have changed and what kind of relationship has changed. Ritual is based on belief. Durkheim states: "Only after having defined the belief can we define the rite" $(1995,34)$. We also often use rituals as common practices in religion, so if religion can be separated from nonreligious areas there is a hope for the definition of ritual. Defining religious ritual will be the first step to defining ritual.

Fortunately attempts to define religion have recently evolved. In his study, Cai divides mental existence into two types: mental existence without material support (ME1) and with physical support (ME2). There are two kinds of ME1, spirit and demon. There are two kinds of ME2, human and medium. After distinguishing between these forms of mental existence, Cai defines religion as an association between two types of mental existence (2013).

In Gluckman's view, ritual changes the social relations between people, which leads to the "boarding ritual" above. In my view, a change in relationship is very important, but what ritual intends to change is not social relations between people but the ME1 and ME2. I define ritual in religion as follows:

\section{Rituals are acts aiming to change the relationship between the ME1 and ME2.}

In this definition I put the subjective judgment of the actor but not the ritual object in the first place, the actor including demander who wants to do the ritual, and performer who does the ritual. As long as there is an action in order to change the relationship between ME1 and ME2, the action is ritual. Whether an action is a ritual is thus determined by the demander's and/or the performer's belief, rather than by ritual objects or other members of society. There is thus individual ritual, which is only acknowledged by the actor himself but not by other social members.

As in the prior analysis of change in social relations, the change in relationship occurs because one end of the relation changes, or both ends change: ME1 changes, ME2 changes, or ME1 and ME2 both change. In real society, people change ME1 for the purpose of changing ME2. There is no pure sword action only aiming at ME1, so the ritual also has two categories:

Ritual 1 (R1): the actor intends to change ME1.

Ritual 2 (R2): the actor intends to only change ME2, but it will change the relationship between the two MEs.

It is an R1 when the actor consciously induces a change in ME1, including pleasing, soothing, intimidating, or overcoming. There are some actions of which the ultimate goal is not ME1, such as praying for rain, but as long as the necessary condition of the ultimate goal includes ME1's change and the actor has a clear consciousness about 
ME1's change and takes action, this action is an R1. There are other behaviors such as conversion in which there is no change in ME1 on the surface, but are still carried out in order to change ME1's attitude toward ME2.

Sometimes, an R1 is permorfed to change the detectability of ME1 or ME2. For example, people take certain actions to make ME2 unperceivable to ME1, or to make ME1 perceivable to ME2. If the behavior is only considered to change the ME2, and has nothing to do with ME1, then it is not an R2.

The actor does not consider ME1 at the beginning of the act, which was not a ritual. Once he/she takes into account that the actions will lead to a change in ME1, the act is transformed into a ritual. After the action when the actor realizes that his/her behavior will cause a change in ME1, the action is still not a ritual. If the actor does not acknowledge the reality of ME1 and uses some action of "desecration" against those who acknowledge ME1, these actions are not a ritual.

Rituals must be religious actions, but the reverse is not true. At least two types are not included. The first type only changes ME2 but does not think that it will affect the ME1, such as a religious believer trying to improve the level of their religious knowledge by studying religious classics (but as long as the believer thinks that the study process will affect ME1, the study process becomes ritual). In the second type the actors do not believe that there is ME1 when they act, but other members of society believe that this behavior causes a change in ME1.

\section{Conclusion}

With so much effort, we are fortunate to continue to use ritual as an analytical tool. If this definition succeeds, it will greatly simplify our research work, and will also clearly define the objectives for our ritual study.

First, my definition is given for ritual in religion. In my opinion, there is no secular ritual so the definition applies to all rituals. In the future, if we can find some actions wanting to change a certain category of existence different from general behavior, it will not be too late to enlarge the limitations of ritual.

Second, whether an action is a ritual depends on the actor's belief. If the actor thinks that his action will influence ME1, the action is a ritual. One ritual will become a common behavior when the actor does not believe it has the effect on ME1. In many societies, one of the most common phenomena is that although people no longer believe in some sort of ritual that can change ME1, they also act according to the process of the ritual behavior for some reason. What people are then doing is no longer a ritual, just a set of behaviors that has the same process as the ritual. Yet, if the actor "finds" a common behavior can affect ME1, the behavior becomes ritual.

"Sacrificing to the spirits, you should comport yourself as if the spirits were present" (Confucius 2003, Book 3.12), the sacrifice is not a ritual. Sometimes people use certain characteristics of traditional rituals to create new behaviors. These behaviors are ubiquitous in nonreligious life, such as secular weddings, graduation ceremonies, or inaugurations. Because of these seemingly ritual processes, we have an unclear understanding of rituals; we may call them ceremonies instead.

Third, the concept of the rite of passage will be abandoned. People believe that a behavior process is needed to change the ritual object, which does not necessarily have a particular structure. 
Fourth, the key to ritual is that people believe that certain behaviors can affect the ME1, so it does not matter whether such behaviors are performed according to fixed procedures. Just like the ancestor worship of Yiche, there are differences between the patrilineages. Our focus will be on how ritual leads to a change in ME 1 and/or 2 and the corresponding technique, rather than on the vague meanings that even local people cannot determine exactly (Bloch 2004).

Finally, we leave the generating questions of ritual to cognitive psychology and other disciplines. Perhaps they can solve these puzzles in the future (Boyer 2001; Stausberg 2009).

\section{Endnotes}

${ }^{1}$ Leach did not differentiate in usage between ritual and ceremony.

${ }^{2}$ In general, anthropologists give the term "rite" the same meaning as the term "ritual."

Funding

This study was funded by the 2011 Humanity and Social Science Fund Youth Project of Ministry of Education

(11yjc730003), and the Scientific Research Foundation for Returned Scholars of Ministry of Education.

Received: 20 March 2018 Accepted: 17 April 2018

Published online: 12 May 2018

References

Bell, Catherine. 1992(2009a). Ritual theory, ritual practice. With a foreword by D. Jonte-Pace. New York: Oxford University Press.

Bell, Catherine. 1997(2009b). Ritual: Perspectives and dimensions. With a foreword by R. Aslan. New York: Oxford University Press.

Bloch, M. 2004. Ritual and deference. In Ritual and memory, ed. H. Whitehouse and J. Laidaw, 65-78. Plymouth: AltaMira Press.

Bourdieu, P. 1980. Le sens pratique. Paris: Editions de Minuit.

Boyer, P. 2001. Religion explained: The evolutionary origins of religious thought. New York: Basic Books.

Buckser, A. 1997. Ritual. In The dictionary of anthropology, ed. T. Barfield, 410. Oxford: Blackwell.

Cai, H. 2000. Une Société sans Père ni Mari. Lse Na de Chine. 4e édition ed. Paris: Presses Universitaires de France.

Cai, H. 2008. L'hommo penseé par L'hommo. Paris: PUF.

Cai, H. 2013. "Esprit Humain Démon (et leur médium): La 'religion' en tant que terme technique demeure-t-elle utile?" http:// jominken.kanagawa-u.ac.jp/triangle/mqgqct0000000nqo-att/HUA_C.pdf

Confucius. 2003. Analects. Indianapolis, IN: Hackett Publishing Company.

Douglas, M. 1966. Purity and danger. London: Routledge.

Durkheim, E. 1995. The elementary forms of religious life. New York: Free Press Original French version: 1912. Les formes élémentaires de la vie religieuse. Paris: Alcan.

Durkheim, E., and M. Mauss. 1969. Primitive classification. With an introduction by R. Needham. London: Cohen \& West.

Evans-Pritchard, E. 1940. The Nuer. Oxford: Clarendon.

Fortes, M. 1962. Ritual and office in tribe society. In Essays on the ritual of social relations, ed. M. Gluckman, 53-88. Manchester: Manchester University Press.

Fox, K. 2004. Watching the English. London: Hodder \& Stoughton.

Gluckman, M. 1962. Les Rites de Passage. In Essays on the ritual of social relations, ed. M. Gluckman, 1-52. Manchester: Manchester University Press.

Goody, J. 1961. Religion and ritual: The definition problem. The British Journal of Sociology 12 (2): 142-164.

Goody, J. 1977. Against 'ritual': Loosely structured thoughts on a loosely defined topic. In Secular ritual, ed. S. Moore and B. Myerhoff, 25-35. Assen/Amsterdam: van Gorcum.

Goody, J. 2010. Religion and ritual from Tylor to Parsons: The definitional problem. In Myth, ritual and the oral, 13-40. New York: Cambridge University Press.

Graburn, N. 1977. Tourism: The Sacred Journey. In Hosts and Guests: The Anthropology of Tourism, ed. V. Smith, 17-34. Philadelphia: University of Pennsylvania.

Graburn, N. 1983. The Anthropology of Tourism. Annals of Tourism Research 10: 9-33.

Grimes, R. 2000. Deeply into the bone: Re-inventing rites of passage. Berkeley: University of California Press.

Héritier, F. 1999. Two sisters and their mother: The anthropology of incest. New York: Zone Books.

Humphrey, C., and J. Laidlaw. 1994. The archetypal actions of ritual. Oxford: Clarendon Press.

Leach, E. 1970 (1954). Political systems of highland Burma: A study of Kachin social structure. London: The Athlone Press.

Leach, E. 1976. Culture and communication: The logic by which symbols are connected. Cambridge: Cambridge University Press.

Nash, D. 1984. The Ritualization of Tourism: Comment on Graburn's The Anthropology of Tourism. Annals of Tourism Research 11: 503-522

Pinker, S. 1998. How the mind works. London: Penguin Press. 
Platvoet, J. 1995. Ritual in plural and pluralist societies: Instruments for analysis. In Pluralism and identity: Studies in ritual behavior, ed. Jan Platvoet and Karel van der Toorn, 25-52. Leiden: Brill.

Rappaport, R. 1984. Pigs for the ancestors. 2nd ed. New Haven, CT: Yale University Press.

Rosaldo, R. 1980. Ilongot headhunting, 1883-1974: A study in society and history. Stanford, CA: Stanford University Press.

Snoek, J. 2006. Defining ritual. In Theorizing Rituals, Issues, Topics, Approaches, Concepts, ed. J. Kreinath, J. Snoek, and M. Stausberg, 3-14. Leiden: Brill.

Stark, R., and W. Bainbridge. 1985. The future of religion. Berkeley: University of California Press.

Stausberg, M., ed. 2009. Contemporary theories of religion. London: Routledge.

Stewart, P., and A. Strathern. 2014. Ritual: Key concepts in religion. London/New York: Bloomsbury.

Turner, V. 1967. The forest of symbols: Aspects of Ndembu ritual. New York: Cornell University Press.

Turner, V. 1974. Dramas, fields, and metaphors: Symbolic action in human society. New York: Cornell University Press.

Turner, V. 1977 (1969). The ritual process: Structure and anti-structure. New York: Cornell University Press.

van Gennep, A. 1960. The rites of passage. Chicago, L: University of Chicago Press Original French version: 1909. Les Rites de Passage. Paris: Nourry.

Winzeler, R. 2012. Anthropology and religion. 2nd ed. Plymouth: AltaMira Press.

Young, M. 2004. Malinowski: Odyssey of an anthropologist, 1884-1920. New Haven, CT: Yale University Press.

Submit your manuscript to a SpringerOpen ${ }^{\odot}$ journal and benefit from:

- Convenient online submission

- Rigorous peer review

Open access: articles freely available online

- High visibility within the field

- Retaining the copyright to your article

Submit your next manuscript at $>$ springeropen.com 